\title{
A retrospective review of oral low-dose sirolimus (rapamycin) for the treatment of active uveitis
}

\author{
Brandon N. Phillips • Keith J. Wroblewski
}

Received: 4 October 2010 /Accepted: 24 November 2010 /Published online: 7 December 2010

(C) The Author(s) 2010. This article is published with open access at Springerlink.com

\begin{abstract}
Purpose The purpose of this study is to elicit the role of oral low-dose sirolimus as a corticosteriod-sparing agent for active uveitis.

Methods A retrospective, interventional case series was performed by reviewing the clinical records of all patients treated with oral, low-dose sirolimus (1-4 mg daily) for severe uveitis. Data reviewed included symptomatic improvement, Snellen best-corrected visual acuity, corticosteroid requirement, sirolimus levels, intraocular inflammation, spectraldomain optical coherence tomography, and fluorescein angiogram. Primary outcome measures were determined by the ability to decrease the intraocular inflammation, corticosteroid requirement, and frequency of flares.

Results Eight patients with varied diagnoses were treated with oral low-dose sirolimus for severe, chronic uveitis between 2008 and 2010. In four of the eight patients, there was an improvement of all primary outcome measures. While sirolimus monotherapy was successful in only one patient, a sirolimus/methotrexate combination was successful in three patients. Although there was a good initial response in three patients, treatment was a failure after serious side effects forced the cessation of sirolimus therapy. One patient was lost to follow-up.
\end{abstract}

Drs. Phillips and Wroblewski are officers in the US Army, and their work therein reflects solely their opinions and not the opinions of the Department of the Army or Department of Defense.

Both authors were involved in the collection, management, analysis, and interpretation of data. The primary author prepared the manuscript and tables. The second author reviewed and edited the manuscript.

B. N. Phillips $(\bowtie) \cdot$ K. J. Wroblewski

Ophthalmology Service, Walter Reed Army Medical Center,

6900 Georgia Avenue NW,

Washington, DC 20307, USA

e-mail: brandon.n.phillips@us.army.mil
Conclusion Sirolimus may have a limited role in severe uveitis as an adjunct corticosteroid-sparing agent in combination with more standard immunosuppressive agents. Oral low-dose sirolimus appeared to be better tolerated than higher doses, but there were a significant number of adverse events, requiring therapy to be stopped.

Keywords Sirolimus · Rapamycin · Uveitis · Inflammation · Immunomodulatory Corticosteroid-sparing agent

\section{Introduction}

Uveitis results from a wide variety of infectious and noninfectious insults, and it often presents a difficult challenge in terms of etiology and treatment. It is estimated that more than 280,000 people in the US are affected by uveitis each year, and it is responsible for up to $10 \%$ of all cases of blindness [1]. Patients can become unresponsive or refractory to topical or oral corticosteroid therapy, requiring other classes of immunomodulatory drugs during the course of their treatment. Methotrexate, cyclosporine, azathioprine, and mycophenolate mofetil are the more common corticosteroid-sparing agents currently used to treat uveitis; however, these agents are limited by a narrow therapeutic window and have significant side effects that often modulate their use.

Sirolimus, also known as rapamycin, inhibits antigeninduced proliferations of $\mathrm{T}$ cells and $\mathrm{B}$ cells and antibody production by inhibiting mTOR, a key regulatory enzyme required for proliferation and differentiation [2]. Sirolimus forms a complex with the intracellular protein FKBP12, which blocks the activation of the cell cycle kinase mTOR, inhibiting the multifunctional serine-threonine kinase, resulting in the blockage of progression at the juncture of 
the $\mathrm{G} 1$ and S phases [3, 4]. As an mTOR inhibitor, sirolimus has a broad spectrum of activity that has demonstrated the ability to inhibit inflammation, proliferation, angiogenesis, fibrosis, and hyperpermeability. Sirolimus currently has multiple uses in the prevention of rejection in organ transplantation and, recently, in the treatment of advanced renal cell carcinoma [5]. Sirolimus-eluting cardiac stents have been shown to limit the rate of overgrowth of tissue and thus prevent coronary restenosis [6]. Early studies suggest that it may be an effective agent for controlling severe uveitis and that it may also have a role in treating agerelated macular degeneration [7].

\section{Methods}

A retrospective chart review of all electronic medical records of patients treated with sirolimus for severe uveitis at the Walter Reed Army Medical Center Ophthalmology Service was completed. The purpose of this study was to elicit the role of low-dose oral sirolimus as a corticosteriod-sparing agent in the treatment of active uveitis. Permission was granted by the Institutional Review Board for this research, and this research adhered to the tenets of the Declaration of Helsinki. All patients had previously had an extensive workup to include laboratory examination, radiologic studies, and biopsy, if necessary. The etiology of the disease was varied, and they are listed in Table 1.

A thorough risk-benefit analysis and discussion of immunomodulatory agents and corticosteriod therapy were had with each patient. Every patient started on sirolimus chose it over a more standard regimen. Patients were started on sirolimus 1-4 mg po daily. Sirolimus blood levels were drawn serially, and sirolimus was titrated to $4-12 \mathrm{ng} / \mathrm{mL}$. For most indications, the target serum blood level of sirolimus is $10-20 \mu \mathrm{g} / \mathrm{mL}$. Both experimental animal and clinical data suggest that adverse events and their associated severity are correlated with blood concentrations [2]. Therefore, low-dose oral sirolimus with a target serum blood level of $4-12 \mu \mathrm{g} / \mathrm{mL}$ should be better tolerated. Patients were monitored regularly to determine effectiveness of the therapy and side effect profiles. Data reviewed included symptomatic improvement, Snellen best-corrected visual acuity, corticosteroid requirement, sirolimus levels, intraocular inflammation determined with slit lamp examination and binocular indirect ophthalmoscopy using standardization of uveitis nomenclature criteria [8], Cirrus spectral-domain optical coherence tomography, and fluorescein angiograms. Primary outcome measures were determined by the ability to decrease the intraocular inflammation, corticosteroid requirement, and frequency of flares.

\section{Results}

Eight patients were treated with oral low-dose sirolimus for active uveitis between 2008 and 2010. The patients' demographics, clinical details, and previous treatments are listed in Table 1. Three patients had a diagnosis of sarcoidosis, two patients had idiopathic uveitis, one patient had sympathetic ophthalmia, one patient had HLA-B27 associated panuveitis, and one patient had intermediate uveitis secondary to Lyme disease. There were six males and two females. The ages ranged from 21 to 79 with a mean age of 47 . Seven of eight patients were previously treated with systemic corticosteroids to control their disease at the initiation of oral, low-dose sirolimus. One patient was started on sirolimus as a first-line agent. Three patients had previously been treated with a subtenons injection of triamcinolone. One patient had been previously treated with a corticosteroid-sparing agent, and one was treated with intravenous methylprednisolone.

The clinical outcomes are listed in Tables 2 and 3. In four of the eight patients, oral low-dose sirolimus was considered a success. The duration of treatment ranged from 21 to 65 weeks, with a mean duration of 44.5 weeks. Patient 1 had an improvement of all primary outcome measures with oral low-dose sirolimus monotherapy. In contrast, patients 2-4 had improvements of all primary outcome measures with a combination of oral low-dose sirolimus and methotrexate. In patients 2 and 3, methotrexate was added to the sirolimus regimen after a flare. Patient 3 had previously failed methotrexate therapy. In patient 4 , oral low-dose sirolimus was added to the methotrexate regimen after a flare.

Treatment was considered a failure in three patients after serious side effects forced the cessation of sirolimus. Patient 5 was found to have a left popliteal deep vein thrombosis during week 8 of sirolimus. It was later discovered that the patient smoked more significantly than initially reported (one pack per day). Patient 6 developed mental status changes due to a recurrence of aseptic meningitis during week 6 of sirolimus. The patient had a history of hepatitis B and one previous episode of aseptic meningitis. The patient recovered with no sequelae. Patient 7 developed thrombocytopenia during week 4 of sirolimus. Her platelet count dropped from 160,000 to 80,000 and rebounded after cessation. However, patients 5 and 6 did have a good initial response to oral low-dose sirolimus therapy. Patient 8 was lost to follow-up.

\section{Discussion}

Sirolimus is a unique and potent agent with broad antiinflammatory and immunomodulatory activities. Early 
Table 1 Patient's demographics, clinical details, and previous treatments

\begin{tabular}{|c|c|c|c|c|c|c|}
\hline Case & Age & Sex & History & Diagnosis & Previous therapy & Reason for sirolimus \\
\hline 1 & 67 & M & $\begin{array}{l}\text { Panuveitis OU with CME OD> } \\
\text { OS treated with topical steroids. }\end{array}$ & Sarcoidosis & $\begin{array}{l}\text { Topical ketorolac, } \\
\text { topical prednisolone }\end{array}$ & $\begin{array}{l}\text { Patient wanted to avoid } \\
\text { oral prednisone }\end{array}$ \\
\hline 2 & 39 & M & $\begin{array}{l}\text { Bilateral recurrent anterior uveitis } \\
\text { and scleritis treated with multiple } \\
\text { orbital floor steroid injections. }\end{array}$ & Sarcoidosis & $\begin{array}{l}\text { Subtenon triamcinolone, } \\
\text { oral prednisone }\end{array}$ & Frequent flares \\
\hline 3 & 31 & $\mathrm{~F}$ & $\begin{array}{l}\text { Chronic anterior uveitis with CME } \\
\text { OD previously treated with prednisone } \\
\text { and methotrexate. Poor control of } \\
\text { inflammation with frequent flares. }\end{array}$ & Idiopathic & $\begin{array}{l}\text { Subtenon triamcinolone, } \\
\text { oral prednisone, oral } \\
\text { methotrexate }\end{array}$ & $\begin{array}{l}\text { Uncontrolled inflammation } \\
\text { with previous regimen }\end{array}$ \\
\hline 4 & 26 & M & $\begin{array}{l}\text { Bilateral chronic intermediate uveitis. } \\
\text { Treated for Lyme disease by } \\
\text { infectious diseases. }\end{array}$ & $\begin{array}{l}\text { Secondary to Lyme } \\
\text { disease }\end{array}$ & $\begin{array}{l}\text { Oral prednisone, oral } \\
\text { methotrexate }\end{array}$ & $\begin{array}{l}\text { Uncontrolled inflammation } \\
\text { with previous regimen }\end{array}$ \\
\hline 5 & 54 & M & $\begin{array}{l}\text { Granulomatous anterior uveitis with } \\
\text { vasculitis and choroidal infiltrates } \\
\text { OD s/p repair of ruptured globe } \\
\text { and eventual enucleation OS. }\end{array}$ & $\begin{array}{l}\text { Sympathetic } \\
\text { ophthalmia }\end{array}$ & $\begin{array}{l}\text { IV methylprednisolone, } \\
\text { oral prednisone }\end{array}$ & $\begin{array}{l}\text { Uncontrolled inflammation } \\
\text { despite maximal dose of } \\
\text { oral prednisone }\end{array}$ \\
\hline 6 & 61 & M & $\begin{array}{l}\text { Panuveitis OU treated with orbital floor } \\
\text { steroid injections and high-dose oral } \\
\text { corticosteroids. History of hepatitis } \\
\mathrm{C} \text { and aseptic meningitis. }\end{array}$ & Sarcoidosis & $\begin{array}{l}\text { Subtenon triamcinolone, } \\
\text { oral prednisone }\end{array}$ & $\begin{array}{l}\text { Avoid higher doses of oral } \\
\text { prednisone }\end{array}$ \\
\hline 7 & 79 & $\mathrm{~F}$ & $\begin{array}{l}\text { Panuveitis with CME OD }>\text { OS treated } \\
\text { with oral corticosteroids. History of } \\
\text { chronic anemia. }\end{array}$ & Idiopathic & Oral prednisone & $\begin{array}{l}\text { Avoid higher doses of oral } \\
\text { prednisone }\end{array}$ \\
\hline 8 & 21 & M & $\begin{array}{l}\text { Recurrent panuveitis treated with high } \\
\text { doses of oral corticosteroids. }\end{array}$ & $\begin{array}{r}\text { HLA B27 } \\
\text { positive }\end{array}$ & Oral prednisone & $\begin{array}{l}\text { Uncontrolled inflammation } \\
\text { despite maximal dose of } \\
\text { oral prednisone }\end{array}$ \\
\hline
\end{tabular}

$F$ female, $M$ male

studies suggest sirolimus may have many diverse roles, including treating patients with retinal thickening secondary to leakage as in neovascular age-related macular degeneration and diabetic macular edema [9]. Sirolimus inhibits the translation and activity of hypoxia-inducible factor- 1 alpha (HIF-1a), a stress-activated protein that is a potent stimulator of vascular endothelial growth factor (VEGF), and its inhibition affects VEGF both upstream at the production level and downstream at the receptor level [10]. This inhibition is a direct effect on the endothelial barrier, independent of vasodilation, and plays an important role in angiogenesis and hyperpermeability [11]. A study showed that sirolimus was superior to VEGF inhibition in a co-culture assay of endothelial cells (EC) and retinal pigment epithelium (RPE) by reducing EC sprouting in groups that did not respond to anti-VEGF treatment and by reducing both VEGF production in RPE and the responsiveness of EC to stimulation [12]. Sirolimus might therefore be a therapeutic option for choroidal neovascularization (NSV) patients that do not respond sufficiently to the established anti-VEGF treatments or may be an excellent combination agent, improving overall outcomes and the intervals between anti-VEGF injections. Sirolimus also has broad inhibitory effects of many inflammatory factors that are not currently addressed in treatment relevant to the development of geographic atrophy, such as fibrosis, leading to irreversible photoreceptor death. It was also reported that, following the administration of sirolimus, there was a reduction of the tumor burden in $\mathrm{LH}_{\mathrm{BETA}} \mathrm{T}_{\mathrm{AG}}$ transgenic retinoblastoma tumors [Murray TG, Piña Y, Houston S, et al. Retinoblastoma Tumor Burden Control: Periocular mTOR Inhibitor Rapamycin Decreases Tumor Burden in Advanced $\mathrm{LH}_{\mathrm{BETA}} \mathrm{T}_{\mathrm{AG}}$ Murine Retinoblastoma. Presented at: Annual Meeting of Association for Research in Vision and Ophthalmology (ARVO); May 2010; Fort Lauderdale, Fla].

The role of sirolimus in treating patients with severe uveitis is evolving. Early studies suggest sirolimus may be an effective agent for controlling uveitis, but its role was not clearly defined [Wroblewski KJ, Sen HN, Yeh S, it al. Combination Daclizumab and Sirolimus Therapy for the Induction of Immune Tolerance in Non-Infectious Intermediate and Posterior Uveitis. Paper presented at: ARVO; May 2009; Fort Lauderdale, Fla]. Two experimental studies using animal models suggested a synergistic therapeutic effect of combination therapy with low doses of calcineurin inhibitors cyclosporine and tacrolimus [13]. A study of human patients with refractory uveitis, limited to patients whose disease was not controlled with at least two or more separate steroid immunosuppressants, showed sirolimus therapy was effective in five of eight patients [14]. 
Table 2 Clinical outcomes

\begin{tabular}{|c|c|c|c|c|c|c|}
\hline Case & $\begin{array}{l}\text { Pre-sirolimus } \\
\text { BCVA }\end{array}$ & $\begin{array}{l}\text { Post-sirolimus } \\
\text { BCVA }\end{array}$ & Clinical course & $\begin{array}{l}\text { Corticosteroid } \\
\text { requirement }\end{array}$ & Clinical outcome & Current therapy \\
\hline 1 & $\begin{array}{l}\text { OD-20/50 } \\
\text { OS-20/25 }\end{array}$ & $\begin{array}{l}\text { OD-20/25 } \\
\text { OS-20/20 }\end{array}$ & $\begin{array}{l}\text { Resolution with sirolimus } \\
2 \mathrm{mg} / \text { day }\end{array}$ & $\begin{array}{l}\text { Did not require } \\
\text { prednisone }\end{array}$ & $\begin{array}{l}\text { Decreased inflammation } \\
\text { Decreased flare rate }\end{array}$ & Sirolimus $2 \mathrm{mg} /$ day \\
\hline \multirow[t]{3}{*}{2} & OD-20/30 & OD-20/15 & $\begin{array}{l}\text { Initial improvement } \\
\text { with a flare } 5 \text { weeks } \\
\text { after starting sirolimus }\end{array}$ & \multirow[t]{3}{*}{$\begin{array}{l}40 \text { to } 5 \mathrm{mg} / \text { day with } \\
\text { sirolimus/MTX } \\
\text { combination }\end{array}$} & Decreased inflammation & Sirolimus $3 \mathrm{mg} /$ day \\
\hline & \multirow[t]{2}{*}{ OS $-20 / 30$} & \multirow[t]{2}{*}{ OS $-20 / 20$} & $\begin{array}{l}\text { No additional flares after } \\
\text { adding MTX }\end{array}$ & & \multirow[t]{2}{*}{ Decreased flare rate } & MTX 20 mg/week \\
\hline & & & & & & Prednisone $5 \mathrm{mg}$ /day \\
\hline \multirow[t]{2}{*}{3} & \multirow[t]{2}{*}{ OD-20/150 } & \multirow[t]{2}{*}{ OD-20/25 } & $\begin{array}{l}\text { No initial improvement } \\
\text { with sirolimus } 2 \mathrm{mg} / \text { day } \\
\text { Increased to } 4 \mathrm{mg} / \text { day and } \\
\text { restarted MTX } 10 \mathrm{mg} / \\
\text { week with resolution } \\
\text { of CME }\end{array}$ & \multirow[t]{2}{*}{$\begin{array}{l}40 \text { to } 5 \mathrm{mg} / \text { day with } \\
\text { sirolimus/MTX } \\
\text { combination. }\end{array}$} & \multirow[t]{2}{*}{$\begin{array}{l}\text { Decreased inflammation, } \\
\text { decreased flare rate }\end{array}$} & $\begin{array}{l}\text { Sirolimus } 4 \text { mg/day } \\
\text { MTX } 10 \mathrm{mg} / \text { week }\end{array}$ \\
\hline & & & & & & Prednisone $5 \mathrm{mg}$ /day \\
\hline \multirow[t]{2}{*}{4} & OD-20/25 & OD-20/20 & \multirow{2}{*}{$\begin{array}{l}\text { Improvement with the } \\
\text { addition of sirolimus } \\
3 \mathrm{mg} / \text { day to MTX } \\
25 \mathrm{mg} / \text { week }\end{array}$} & \multirow[t]{2}{*}{$10 \mathrm{mg} /$ day to tapered off } & \multirow{2}{*}{$\begin{array}{l}\text { Decreased inflammation } \\
\text { Decreased flare rate }\end{array}$} & Sirolimus $3 \mathrm{mg} /$ day \\
\hline & OS-20/25 & OS-20/20 & & & & MTX 25 mg/week \\
\hline \multirow[t]{2}{*}{5} & \multirow[t]{2}{*}{ OD-20/20 } & \multirow[t]{2}{*}{ OD-20/15 } & $\begin{array}{l}\text { Improvement with } \\
\text { sirolimus } 3 \mathrm{mg} / \text { day } \\
\text { and cyclosporine } \\
50 \mathrm{mg} \text { BID }\end{array}$ & \multirow[t]{2}{*}{$\begin{array}{l}20 \text { to } 10 \mathrm{mg} / \text { day while } \\
\text { on sirolimus }\end{array}$} & \multirow[t]{2}{*}{ Failure due to side effects } & $\begin{array}{l}\text { Cyclosporine } 100 \mathrm{mg} \\
\text { BID }\end{array}$ \\
\hline & & & $\begin{array}{l}\text { Sirolimus was stopped } \\
\text { after the patient } \\
\text { developed a DVT }\end{array}$ & & & Prednisone $20 \mathrm{mg}$ /day \\
\hline 6 & $\begin{array}{l}\text { OD-20/30 } \\
\text { OS-20/30 }\end{array}$ & $\begin{array}{l}\text { OD-20/25 } \\
\text { OS-20/20 }\end{array}$ & $\begin{array}{l}\text { Initial improvement of } \\
\text { vision but sirolimus } \\
\text { was stopped due to a } \\
\text { recurrence of aseptic } \\
\text { meningitis }\end{array}$ & Not enough data & Failure due to side effects & Prednisone $20 \mathrm{mg} /$ day \\
\hline \multirow[t]{2}{*}{7} & OD-20/60 & No data & $\begin{array}{l}\text { Platelet count dropped } \\
\text { from } 160,000 \text { to } 80,000 \\
\text { after starting sirolimus }\end{array}$ & \multirow[t]{2}{*}{ Not enough data } & \multirow[t]{2}{*}{ Failure due to side effects } & \multirow[t]{2}{*}{ Prednisone $20 \mathrm{mg} /$ day } \\
\hline & OS $-20 / 50$ & & $\begin{array}{l}\text { Sirolimus was stopped } \\
\text { and the platelets } \\
\text { rebounded }\end{array}$ & & & \\
\hline 8 & $\begin{array}{l}\text { OD- } 20 / 150 \\
\text { OS- }-10 / 100\end{array}$ & No data & $\begin{array}{l}\text { Missed several follow-up } \\
\text { appointments }\end{array}$ & No data & Lost to follow-up & No data \\
\hline
\end{tabular}

MTX methotrexate; $B C V A$ best corrected visual acuity; $C M E$ cystoid macular edema

Table 3 Duration of sirolimus therapy and dosage

\begin{tabular}{cccccccc}
\hline Case & $\begin{array}{l}\text { Duration of therapy } \\
\text { (weeks) }\end{array}$ & $\begin{array}{l}\text { Initial dose } \\
(\mathrm{mg})\end{array}$ & $\begin{array}{l}\text { Final dose } \\
(\mathrm{mg})\end{array}$ & $\begin{array}{l}\text { Weight } \\
(\mathrm{kg})\end{array}$ & $\begin{array}{l}\text { Number of } \\
\text { flares }\end{array}$ & Still taking & Side effects \\
\hline 1 & 65 & 2 & 2 & 95 & 0 & Yes & No significant side effects to date \\
2 & 50 & 3 & 4 & 122 & 1 & Yes & No significant side effects to date \\
3 & 42 & 2 & 4 & 86 & 1 & Yes & No significant side effects to date \\
4 & 21 & 3 & 3 & 102 & 0 & Yes & No significant side effects to date \\
5 & 8 & 2 & 3 & 79 & 1 & No & DVT-left popliteal \\
6 & 6 & 2 & 2 & 72 & 0 & No & Nausea, vomiting, recurrence of aseptic \\
& & 2 & 2 & 64 & 0 & No & Theningitis \\
7 & 2 & 2 & 2 & 80 & No data & No & No data \\
8 & 2 & 2 & &
\end{tabular}


Treatment in three patients was considered a failure due to intolerable side effects or failure to control uveitis. Maximum doses ranged from 4 to $12 \mathrm{mg} /$ day, with blood levels of up to $25 \mathrm{ng} / \mathrm{mL}$. Researchers found that higher blood levels led to an increased side effect profile, mostly dermatological and gastrointestinal in nature, with little additional benefits.

In our series, three out of seven patients stopped taking sirolimus due to a serious side effect. However, two of those patients had significant confounding factors. The other four patients tolerated the medication well with little to no side effects. This could be explained by the relatively low doses of sirolimus used in comparison to the previous study. As a solo immunosuppressive agent, our limited study suggests that oral low-dose sirolimus has little role in the treatment of active uveitis. However, oral low-dose sirolimus used in combination with methotrexate worked well for three patients in this series. Commonly described side effects include anemia, thrombocytopenia, hypercholesterolemia, arthralgias, and gastrointestinal problems. Sirolimus has also been shown to be associated with Bk virus-associated nephropathy, although at the lower end of the range described with various other contemporaneous immunosuppressive regimens [15].

Since oral or intravenous administration presents the issues of systemic immunosuppression and side effects, investigators have been evaluating the safety, tolerability, and biological activity of sirolimus when delivered by either a subconjunctival or intravitreal injection, making systemic exposure negligible. Animal studies have shown that there is no retinal toxicity with intravitreal sirolimus injections [16, 17]. It was recently suggested that retinal and choroidal sirolimus levels are sustained longer, following subconjunctival injection, as the sclera acts as a reservoir for the highly lipophilic drug [Nivaggioli T, Bao JX, Farooq S, et al. Pharmacokinetics of a locally administered subconjunctival ocular formulation of sirolimus in rabbits and humans. Paper presented at: ARVO; May 2009; Fort Lauderdale, Fla]. There were no dose-limiting toxicities, ocular inflammation, or increase in intraocular pressure.

\section{Conclusion}

Oral low-dose sirolimus appears to have a limited role in active uveitis as an adjunct corticosteroid-sparing agent in combination with more standard immunosuppressive agents. Oral low-dose sirolimus appeared to be better tolerated than higher doses, but there were a significant number of adverse events, requiring therapy to be stopped. The study suffers from limited numbers and a selection bias. Sirolimus should only be used after proper patient selection with an extensive risk-benefit analysis and a thorough discussion with the patient. Patients taking sirolimus need close monitoring, including necessary lab work such as blood levels, CBCs, liver function tests (LFT), and lipid levels.

Funding/Support None.

Financial disclosures None.

Conformity Approved by the IRB at Walter Reed Army Medical Center

Open Access This article is distributed under the terms of the Creative Commons Attribution License which permits any use, distribution and reproduction in any medium, provided the original author(s) and source are credited.

\section{References}

1. Gritz DC, Wong IG (2004) Incidence and prevalence of uveitis in Northern California: the Northern California epidemiology of uveitis study. Ophthalmology 111(3):491-500

2. Buhaescu I, Izzedine H, Covic A (2006) Sirolimus-challenging current perspectives. Ther Drug Monit 28:577-584

3. Sehgal SN (2003) Sirolimus: its discovery, biological properties, and mechanism of action. Transplant Proc 35(Suppl 3A):7S-14S

4. Dutcher JP (2004) Mammalian target of rapamycin inhibition. Clin Cancer Res 10:63282S-66387S

5. Hudes GR, Berkenbilt A, Feingold J, Atkins MB, Rini BI, Dutcher J (2009) Clinical trial experience with temsirolimus in patients with advanced renal cell carcinoma. Semin Oncol 36 (Suppl 3):S26-S36

6. Greenhalgh J, Hockenhull J, Rao N, Dundar Y, Dickson RC, Bagust A (2010) Drug-eluting stents versus bare metal stents for angina or acute coronary syndromes. Cochrane Database Syst Rev 5:CD004587

7. Mousa SA, Mousa SS (2010) Current status of vascular endothelial growth factor inhibition in age-related macular degeneration. BioDrugs 24(3):183-194

8. Jabs DA, Nussenblatt RB, Rosenbaum JT (2005) Standardization of Uveitis Nomenclature (SUN) working group. Standardization of uveitis nomenclature for reporting clinical data. Results of the first international workshop. Am J Ophthalmol 140:509-516

9. Barakat MR, Kaiser PK (2009) VEGF inhibitors for the treatment of neovascular age-related macular degeneration. Expert Opin Investig Drugs 18(5):637-646

10. Hudson CC, Liu M, Chiang GG et al (2002) Regulation of hypoxia-inducible factor 1alpha expression and function by the mammalian target of rapamycin. Mol Cell Biol 22:70047014

11. Kleinman DM, Kim DD, Nivaggioli T et al (2007) Sirolimus Inhibits VEGF-Induced Microvascular Hyperpermeability. Invest Ophthalmol Vis Sci 48:1422

12. Stahl A, Paschek L, Martin G et al (2008) Rapamycin reduces VEGF expression in retinal pigment epithelium (RPE) and inhibits RPE-induced sprouting angiogenesis in vitro. FEBS Lett 582(20):3097-3102, Epub 2008 Aug 12 
13. Martin DF, DeBarge LR, Nussenblatt RD et al (1995) Synergistic effect of rapamycin and cyclosporin $\mathrm{A}$ in the treatment of experimental autoimmune uveoretinitis. J Immunol 154:922-927

14. Shanmuganathan VA, Casely EM, Powell RJ et al (2005) The efficacy of sirolimus in the treatment of patients with refractory uveitis. Br J Ophthalmol 89:666-669

15. Benavides CA, Pollard VB, Mauiyyedi S, Podder H, Knight R, Kahan BD (2007) BK virus-associated nephropathy in sirolimus- treated renal transplant patients: incidence, course, and clinical outcomes. Transplantation 84(1):83-88

16. Douglas LC, Yi NY, Davis JL, Salmon JH, Gilger BC (2008) Ocular toxicity and distribution of subconjunctival and intravitreal rapamycin in horses. J Vet Pharmacol Ther 31(6):511516

17. Manzano RP, Peyman GA, Khan P, Kivilcim M, Chevez-Barrios $\mathrm{P}$, Takahashi W (2009) Testing intravitreal toxicity of rapamycin in rabbit eyes. Arq Bras Oftalmol 72(1):18-22 